\title{
Effect of Arbuscular Mycorrhizal Fungi on Growth and Nutrient Status of Vigna unguiculata (L.)
}

\author{
Sameer Ahmad Thoker, Sapan Patel* \\ School of Studies in Botany, Jiwaji University Gwalior M.P., India \\ Received April 14, 2020; Revised June 30, 2020; Accepted July 24, 2020
}

\section{Cite This Paper in the following Citation Styles}

(a): [1] Sameer Ahmad Thoker, Sapan Patel, "Effect of Arbuscular Mycorrhizal Fungi on Growth and Nutrient Status of Vigna unguiculata (L.)," Advances in Zoology and Botany, Vol. 8, No. 5, pp. 461 - 467, 2020. DOI: 10.13189/azb.2020.080511.

(b): Sameer Ahmad Thoker, Sapan Patel (2020). Effect of Arbuscular Mycorrhizal Fungi on Growth and Nutrient Status of Vigna unguiculata (L.). Advances in Zoology and Botany, 8(5), 461 - 467. DOI: 10.13189/azb.2020.080511.

Copyright $(\mathrm{C} 2020$ by authors, all rights reserved. Authors agree that this article remains permanently open access under the terms of the Creative Commons Attribution License 4.0 International License

\begin{abstract}
Since last three decades, the increased use of chemical fertilizers in agriculture undoubtedly increased the food grain production and helped the country in achieving self-sufficiency in food grains. However, it also produced many harmful effects like water supply contaminations, shortage of quality of agricultural products and decrease in the amount of soil fertility. The study was performed to evaluate whether Arbuscular Mycorrhizal Fungi (AMF) improved Growth and Nutrient status in some important annual leguminous crops using Cow pea (Vigna unguiculate L) as a study material. Arbuscular mycorrhizal fungi (AMF) are important soil organisms belonging to phylum Glomeromycota and form symbiotic association with the roots of 70-90\% plant species. A pot experiment was conducted at Botanical Garden, School of Studies in Botany Jiwaji University Gwalior during the year 2019 to study the effect of arbuscular mycorrhizal fungi viz Glomus hoi and Acaulospora kentinensis on seed germination, growth and biochemical contents of cow pea Vigna unguiculata $\mathrm{L}$. The Plants were raised in triplicates through the pot culture. The seeds were surface sterilized by hypochlorite solution before sowing. Pots were placed at a sunny place after the seed sowing. And after the seed germination, plants were irrigated when required. After germination the inoculated plants along with their controls was sampled. The results showed that Glomus hoi and Acaulospora kentinensis significantly increased growth parameters like root and shoot length, total leaf area, fresh and dry weight of roots and shoots in Vigna unguiculata L. Inoculation of Glomus hoi and Acaulospora kentinensis significantly increases the biochemical constituents like
\end{abstract}

chlorophyll- a, chlorophyll-b, total chlorophyll, protein, carbohydrate, reducing sugar, non reducing sugar and total phenol. The present study pertains that AMF colonization improved positively the overall growth and development of cow Pea plant.

Keywords Cowpea, Arbuscular Mycorrhizal Fungi, Growth Parameters, Chlorophyll and Biochemical Constituents

\section{Introduction}

Cowpea (Vigna unguiculata L.) is an important crop commonly called as poor man's meat because of its sufficiently great source of vitamins, proteins and minerals for poor people who are not able to get such nutrients from animal source like fish and meat (Gondwe et al., 2019). The green pods and leaves are used as vegetable and the dried grain is used for the preparations of different foods. However, the production and productivity of cow pea is low because of lack of improved cultivators, limited input use, poor management practices and use of chemical fertilizers and pesticides (Kyei-Boahen et al., 2017). Hence for sustainable agriculture, all efforts should be streamlined to increase production and productivity of cowpea (Jain, 2018). In this context, now a day's bio fertilizers are gaining much importance in agriculture. Biofertilizers are not only organic material resulted from animal residues, plant residues and so on. They also include products results from microorganism's activities that act in relation to 
nitrogen stabilization or phosphorus and other nutrient elements preparations that act in soil (Johnson et al., 2015). One of the available ways to reach permanent agriculture is using some microorganisms that have important role in supplying food requirements like mycorrhizal fungi. Mycorrhizal fungi are used in conventional agriculture to improve crop production and productivity (Gianinazzi et al., 2010). The tremendous advances in mycorrhizal research over the past years have led to a greater understanding of the multiple roles of mycorrhizal fungi in the agricultural ecosystem. Mycorrhizae are a symbiotic relationship between a fungus and roots of plants (Shuab et al., 20016). On the basis of penetration there are two types of mycorrhiza viz Ecto mycorrhiza and Endo mycorrhiza. Ectomycorrhiza do not penetrate within the roots while Endo mycorrhiza penetrates cell wall and reaches into the cell membrane (Smith et al., 2017). Arbuscular mycorrhizal fungus belongs to division Glomeromycota and forms symbiosis with eighty five percent of all plant families (Lone et al., 2015). Arbuscular mycorrhizal fungi colonize roots and form two types of mycelium, intra radical mycelium (IRM) and extra radical mycelium (ERM). Arbuscules are the characteristic intra radical mycelium structures that are highly branched within host cells in order to mediate resource exchange between the symbionts. They are ephemeral structures and at the end of their life span, arbuscular branches collapse from the tip, fungal cytoplasm withdraws and the whole arbuscules shrinks into the fungal clumps. The exoskeleton of an arbuscule shrinks into the fungal clumps. The exoskeleton of an arbuscule contains structured chitin, which is a polymer of $\mathrm{N}$-acetyl glucosamine; whereas collapsed arbuscule does not have chitin (Kobae et al., 2015). Arbuscular mycorrhizal fungi benefit their host plant by improving the uptake of minerals, water and poorly mobile phosphorus in the soil. The fungus has shown to improve the tolerance of plants to drought stress (Van Der Heijden et al., 2015). AMF are beneficial soil symbionts which establish mutualistic association with the roots of $80 \%$ of Plant species and the large majority of food crops including cereals, Legumes vegetables and fruits (Pepe et al., 2018). Research suggests that arbuscular mycorrhizal fungi might foster upper range expansion of invasive tress over non-invaded higher elevations. The effect of these AMF communities on plant growth and nutrition shows that arbuscular mycorrhizal fungi can facilitate the growth of alien tress in non-invaded mountain ecosystems (Urcely, 2019). Inoculation of AMF optimizes the production of bioactive compounds in the plants which in turn increases the production of secondary metabolites. In those plants which show AMF association the flavonoid concentration increases as reported in Libidubia ferrea in the field conditions (Santos et al., 2017). Glomus hoi is an arbuscular mycorrhizal fungi belongs to family Glomeraceae and division Glomeromycota. It forms symbiotic association with several plants and helps plants in increasing growth and biochemical parameters. Glomus hoi is found in several agricultural regions of India like M.P, Himachal and Kashmir regions (S. Varga., 2009). Acaulospora kentinensis is a species of Arbuscular Mycorrhizal fungi belonging to the family Acaulosporaceae. It forms mycelium, vesicles and arbuscules with roots of several plant (Janos DP and Trappe JM., 1982). In the present study the above two species were used because they are native to Madhya Pradesh region as we have isolated these two fungi from rhizospheric regions of several agricultural sites of Gwalior region.

\section{Materials and Methods}

\section{Seeds, Soil, Arbuscular Mycorrhizal Inoculation and Experimental Design}

The seeds of Vigna unguiculata (L) were collected from Agriculture Collage Gwalior. Seeds were surface sterilized by dropping them in $4 \%$ sodium hypochlorite for 10 minutes. Then seeds were washed 3-4 times by distilled water. Before sowing the seeds in pots, the germination rate was calculated. The germination percentage were calculated by the following equation

\section{Germination percentage $=$ Seeds germinated $/$ Total seeds X 100}

Seeds were sown in pots in triplicates for each species along with control. Two types of Arbuscular Mycorrhizal Fungal Spores Glomus hoi and Acaulospora kentinensis were used separately and in combination. The two fungi were collected from different agricultural zones of Gwalior Region. The soil was collected from the rhizospheric regions of plant and isolation of fungi were done by the method of Gerdman and Nicholson (1963). Since these two Arbuscular Mycorrhizal fungi are non-culturable on any media, therefore we got the cultures of these two fungi from the energy and resource institute New Delhi under Material Transfer agreement.

For the current study 40 pots were used. Ten pots were filled with soil inoculated with Glomus hoi, Ten with Acaulospora kentinensis, ten with combination of Glomus hoi and Acaulospora kentinensis and ten pots were filled with sterilized soil without inoculation of spores. Finally, four sets of Pots were made viz Species A, Species B, Species A+B and Control

[Where

$\mathrm{A}=$ Pots filled with Glomus hoi

$\mathrm{B}=$ Pots filled with Acaulospora kentinensis

$\mathrm{C}=$ Pots filled with the combination of Glomus hoi and Acaulospora kentinensis

And

$D=$ Pots filled with no spores] 
All the pots were filled with sterilized soil which autoclaved twice at $15 \mathrm{lbs}$ pressure at $120^{\circ} \mathrm{C}$ temperature for 45 minutes. The pot experiment was conducted at Botanical Garden of School of studies in Botany, Jiwaji University Gwalior. The pots were placed in sunny area. After germination the pots were irrigated when needed. After germination the inoculated plants along with their controls was sampled at 30days for growth and other biochemical constituents.

Table 1. Some physical properties of soil which was used in pot culture

\begin{tabular}{|c|c|}
\hline Colour & Reddish brown \\
\hline Texture & clay loamy \\
\hline $\mathrm{pH}$ & 7.12 \\
\hline Electric conductivity(dsm-1) & 0.24 \\
\hline Organic carbon (percent) & 0.39 \\
\hline Moisture content (percent) & 6.34 \\
\hline Water holding capacity (percent) & 2.32 \\
\hline Density(mg. m-3) & 1.21 \\
\hline
\end{tabular}

Table 2. Macro and Micronutrient analysis of soil used for the experiment

\begin{tabular}{|c|c|}
\hline Nitrogen (kg. ha-1) & 160 \\
\hline Phosphorous (kg. ha-1) & 14.60 \\
\hline Potassium (kg. ha-1) & 230.42 \\
\hline Iron (ppm) & 5.40 \\
\hline Zinc (ppm) & 1.23 \\
\hline Manganese (ppm) & 6.20 \\
\hline Copper (ppm) & 1.66 \\
\hline
\end{tabular}

\section{Plant Growth Parameters and AMF Colonization}

Plant Height $(\mathrm{cm})$, Plant Width at Base $(\mathrm{cm})$, Total number of leaves per plant, Largest Leaf length Base to tip $(\mathrm{cm})$ and Root length Bulb base to tip. $(\mathrm{cm})$ were recorded. Roots was collected and placed in 4\% isopropanol solution for analysis of AMF colonization. The roots were stained with $0.05 \%$ tryphan blue stain using the method suggested by Phillips and Hayman (1970).

Estimation root colonization was carried by using Biermann and Linderman (1981) method. Percent root colonization was calculated using following equation

Root colonization $(\%)=$

Number of arbuscular mycorrhizal positive segments

Total number of segments studied X 100

\section{AMF from rhizosphere}

For the separation of AMF spore from the rhizospheric region of the soil the method of wet sieving and decanting proposed by Gerdemann and Nicolson (1963) were used. 100 gram rhizosphere soil was suspended in $1000 \mathrm{ml}$ of tap water. The mixture was stirred for half an hour and the heavier soil and sand particles were allowed to settle down to the bottom. The soil water mixture was decanted through sieves arranged in descending order $(240 \mu \mathrm{m}, 120 \mu \mathrm{m}$, $60 \mu \mathrm{m}, 30 \mu \mathrm{m}$,). Top sieve captured roots and debris. Debris from the remaining sieves was collected separately in beakers. Spores were collected in a petriplate of $10 \mathrm{~cm}$ diameter and were examined under stereo-microscope. The manual provided by Schenck and Perez (1990) were used for the identification of different species of AMF.

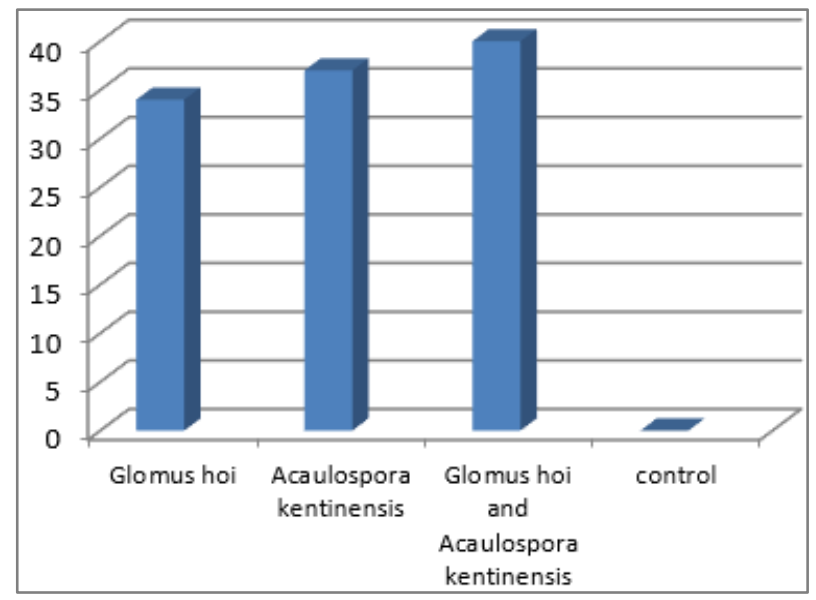

\section{Chlorophyll and Other Biochemical parameters}

For Chlorophyll a, Chlorophyll b and total chlorophyll Method of Arnon (1949) and Witham et al. (1971) was used. Following equation was used to determine the chlorophyll present in the extract as mg chlorophyll per gram green tissue using the following equations for each fraction;

For chlorophyll a

mg chlorophyll a per gm tissue $=12.7($ A663 $)-269($ A645 $)$ $\frac{\mathrm{V}}{\times 1000 \times \mathrm{W}}$

For chlorophyll b

$\mathrm{mg}$ chlorophyll $\mathrm{b}$ per gm tissue $=12.7(\mathrm{~A} 645)-269(\mathrm{~A} 663)$

$$
\times \frac{\mathrm{V}}{1000 \times \mathrm{W}}
$$

Total chlorophyll

$\mathrm{mg}$ total chlorophyll $=20.2(\mathrm{~A} 645)+8.02(\mathrm{~A} 663) \times$ $\mathrm{V}$

$$
\begin{aligned}
& 1000 \times W \\
& \text { Where }
\end{aligned}
$$

$\mathrm{A}=$ absorbance at specific wavelength

$\mathrm{V}=$ final volume of chlorophyll extract in $80 \%$ acetone

$\mathrm{W}=$ fresh weight of tissue extracted

\section{Biochemical parameters}

Protein estimation by Lowry's et al., (1951) method.

Extraction of protein from Sample: Extraction is usually 
carried out with buffers used for the enzyme assay. Weigh $500 \mathrm{mg}$ of the sample and grind well with a pestle and mortar in $5-10 \mathrm{~mL}$ of the buffer. Centrifuge and use the supernatant for protein estimation.

\section{Estimation of Protein:}

1. Pipette out $0.2,0.4,0.6,0.8$ and $1.0 \mathrm{ml}$ of the working standard into a series of test tubes.

2. Pipette out $0.1 \mathrm{ml}$ and $0.2 \mathrm{ml}$ of the sample extract in two other test tubes. 3. Make up the volume to $1.0 \mathrm{ml}$ in all the test tubes. A tube with $1.0 \mathrm{ml}$ of water serves as the blank. 4. Add $5.0 \mathrm{ml}$ of reagent $\mathrm{C}$ to each tube including the blank. Mix well and allowed to standing for 10mins. 5 . Then add $0.5 \mathrm{ml}$ of reagent $\mathrm{D}$, Mix well and incubate at room temperature in the dark for $30 \mathrm{~min}$, blue colour is developed. Take the reading at $660 \mathrm{~nm}$.Draw a standard graph and calculate the amount of protein in the sample.

Estimation of sugar content (Total, reducing sugar and Non reducing sugar)-

The total and reducing sugar contents were analyzed in host plant shoot and root parts by the Nelson-Somogy method (Nelson, 1944).

\section{Procedure:}

\section{(i) Total sugars content}

To $1 \mathrm{ml}$ alcoholic aliquot, $1 \mathrm{ml} 1 \mathrm{~N} \mathrm{H} 2 \mathrm{SO} 4$ was added and heated at $490 \mathrm{C}$ in water bath for 30 minutes for hydrolysis of the mixture. 1-2 drop of methyl red indicator was added. $1 \mathrm{~N} \mathrm{NaOH}$ was added dropwise for the neutralization (Colour was to yellow from pink). $1 \mathrm{ml}$ Nelson Somogy's reagent was added to it and the tube was kept in boiling water bath for 20 minutes. After cooling of the test tube, $1 \mathrm{ml}$ arsenomolybdate was added and final volume was made up to $20 \mathrm{ml}$ with distilled water and optical density was noted at $540 \mathrm{~nm}$. Blank was prepared in the same manner. A standard curve was prepared using glucose in $\mu \mathrm{g}$ per $\mathrm{ml}$.

\section{(ii) Reducing sugars contents}

To $1 \mathrm{ml}$ alcoholic aliquot, Nelson Somogy's reagent was added and kept in boiling water bath for $20 \mathrm{~min}$. After cooling of the test tube, $1 \mathrm{ml}$ arsenomolybdate was added and final volume was made up to $20 \mathrm{ml}$ with distilled water and optical density was noted at $540 \mathrm{~nm}$. Blank was prepared in the same manner.

(iii) Non-reducing sugar $=$ Total sugar - Reducing sugar. The result was expressed as mg/g-1 plant material.

\section{Results}

\section{Root Colonization}

The germination percentage of seeds was 100 percent. The roots of the cowpea plants in the control pots did not show any of the AMF structures. Pots inoculated with Glomus hoi shows minimum root colonization. Plant root percentage colonization of AMF was higher in the pots inoculated with the combination Glomus hoi and Acaulospora kentinensis (as shown in the following Figure). Mycorrhizal Colonization is confirmed in all pots inoculated with AMF. This finding is based on the presence of AMF in various morpho-presentations like hyphae, arbuscules or vesicles, in the infected roots.

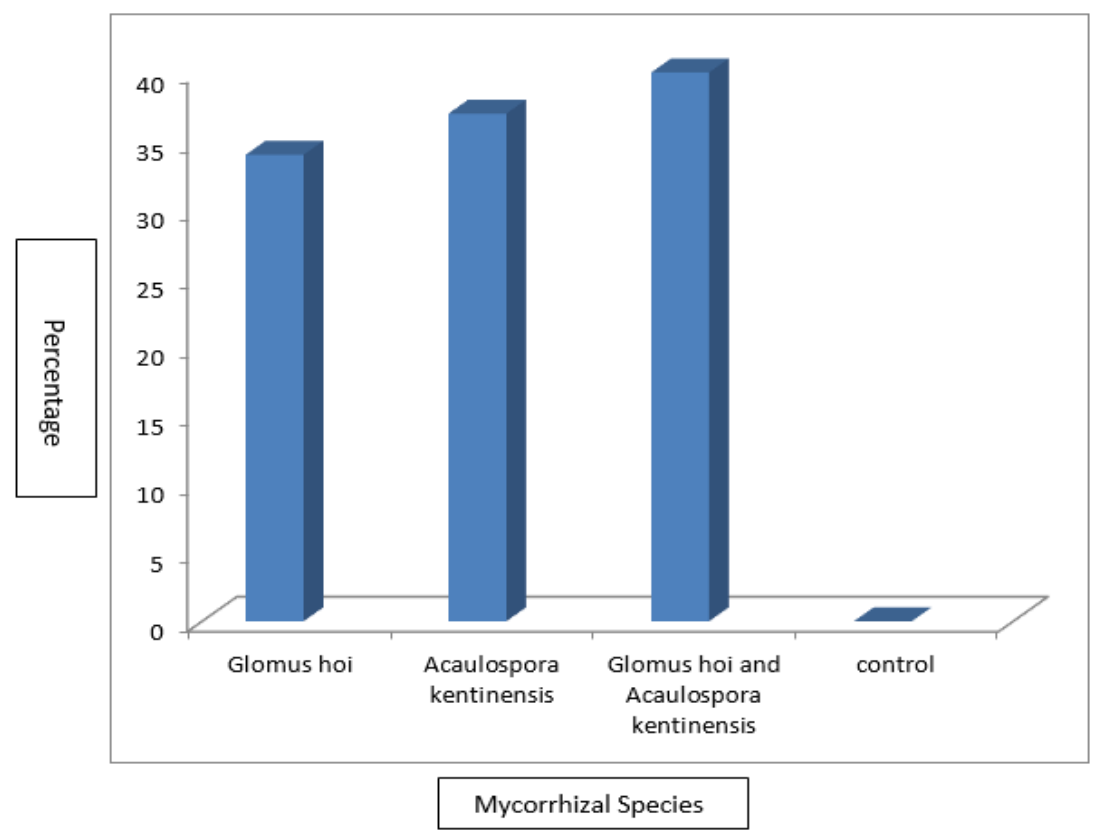




\section{Growth parameters}

Plants height of all treatments was measured at the flowering/fruiting stage (45 days after sowing). To evaluate shoot and root parameters, all plants were harvested at the flowering/fruiting stage. Plants without AMF inoculation don't show any significant increase in plant width, number of branches per plant, leaf length and root length whereas plant inoculated with different mycorrhizal species shows significant increase in several growth and developmental parameters. Pots inoculated with Acaulospora kentinensis shows maximum increase in plant height while as pots inoculated with the combinations of Glomus hoi and Acaulospora kentinensis showed increase in plant width and total number of leaves. The largest root length was found in plants inoculated with Species Glomus hoi and largest leaf area was also found in plants inoculated with the combinations of species Glomus hoi and Acaulospora kentinensis (Table 3)

Table 3. Various Growth and developmental parameters of cow pea plant as affected by the presence of AMF

\begin{tabular}{|c|c|c|c|c|c|}
\hline Specie & $\begin{array}{c}\text { Plant height }(\mathbf{c m}) \\
\text { (Average } \pm \text { Standard } \\
\text { error) }\end{array}$ & $\begin{array}{c}\text { Plant width (cm) } \\
\text { (Average } \pm \text { Standard } \\
\text { error) }\end{array}$ & $\begin{array}{c}\text { Total number of } \\
\text { leaves (Average } \pm \\
\text { Standard } \\
\text { error) }\end{array}$ & $\begin{array}{c}\text { Largest leaf area (cm) } \\
\text { (Average } \pm \text { Standard } \\
\text { error) }\end{array}$ & $\begin{array}{c}\text { Root length(cm) } \\
\text { (Average } \pm \text { Standard } \\
\text { error) } \\
\text { Glomus hoi }\end{array}$ \\
\hline $\begin{array}{c}\text { Acaulospora } \\
\text { kentinensis }\end{array}$ & $30.4 \pm 0.02$ & $1.3 \pm 0.03$ & $2.0 \pm 0.02$ & $6.5 \pm 0.03$ \\
\hline $\begin{array}{c}\text { Glomus hoi } \text { and } \\
\text { Acaulospora } \\
\text { kentinensis }\end{array}$ & $30 \pm 0.03$ & $1.3 \pm 0.01$ & $2.0 \pm 0.03$ & $7.1 \pm 0.01$ \\
\hline control & $25.5 \pm 0.01$ & $1.2 \pm 0.02$ & $2.4 \pm 0.02$ & $6.810 .7 \pm 0.02$ \\
\hline
\end{tabular}

\section{Chlorophyll Contents}

Chl a content in plants inoculated with species Acaulospora kentinensis was more as compared to plants inoculated with species Glomus hoi and in combinations of Glomus hoi and Acaulospora kentinensis. The plants which were inoculated with the Glomus hoi and combinations of Glomus hoi and Acaulospora kentinensis showed increase in chlorophyll b. Total chlorophyll was high in the plants which were inoculated with Acaulospora kentinensis. Plants without AMF inoculations show minimum concentrations of Chl a, Chl b and total chlorophyll (Table 4).

Table 4. Leaf chlorophyll contents in the plant with and without the presence of AMF at various growth stages (mg/g fresh weight)

\begin{tabular}{|c|c|c|c|}
\hline Species & $\begin{array}{c}\text { Chlorophyll a } \\
\text { (Average } \pm \text { Standard error) }\end{array}$ & $\begin{array}{c}\text { Chlorophyll b } \\
\text { (Average } \pm \text { Standard error) }\end{array}$ & $\begin{array}{c}\text { total chlorophyll } \\
\text { (Average } \pm \text { Standard error) }\end{array}$ \\
\hline Glomus hoi & $0.06 \pm 0.00$ & $0.12 \pm 0.02$ & $0.19 \pm 0.00$ \\
\hline Acaulospora kentinensis & $0.07 \pm 0.00$ & $0.10 \pm 0.00$ & $0.21 \pm 0.00$ \\
\hline $\begin{array}{c}\text { Glomus hoi and } \\
\text { Acaulospora kentinensis }\end{array}$ & $0.47 \pm 0.1$ & $0.12 \pm 0.00$ & $0.19 \pm 0.00$ \\
\hline control & $0.06 \pm 0.00$ & $0.09 \pm 0.00$ & $0.16 \pm 0.00$ \\
\hline
\end{tabular}

\section{Fresh and dry weight}

The fresh and dry weight of cow pea plants shows increase with the inoculation of different AMF species. Plants inoculated with species Acaulospora kentinensis shows significant increase in fresh and dry weight of root and shoot. (Table 5).

Table 5. Fresh and dry matter content with and without AMF in the plant (gram/plant)

\begin{tabular}{|c|c|c|c|c|c|c|}
\hline Species & $\begin{array}{c}\text { Root fresh } \\
\text { (Average } \pm \\
\text { Standard } \\
\text { error) }\end{array}$ & $\begin{array}{c}\text { Shoot fresh } \\
\text { (Average } \pm \\
\text { Standard error) }\end{array}$ & $\begin{array}{c}\text { Total fresh } \\
\text { (Average } \pm \\
\text { Standard error) }\end{array}$ & $\begin{array}{c}\text { Root Dry } \\
\text { (Average } \pm \\
\text { Standard error) }\end{array}$ & $\begin{array}{c}\text { Shoot Dry } \\
\text { (Average } \pm \\
\text { Standard error) }\end{array}$ & $\begin{array}{c}\text { Total Dry } \\
\text { (Average } \pm \\
\text { Standard error) }\end{array}$ \\
\hline Glomus hoi & $0.12 \pm 0.22$ & $1.34 \pm 0.04$ & $1.46 \pm 0.12$ & $0.088 \pm 0.01$ & $0.357 \pm 0.03$ & $0.445 \pm 0.68$ \\
\hline $\begin{array}{c}\text { Acaulospora } \\
\text { kentinensis }\end{array}$ & $0.49 \pm 0.22$ & $2.25 \pm 0.03$ & $2.74 \pm 0.13$ & $0.089 \pm 0.02$ & $0.543 \pm 0.01$ & $0.632 \pm 0.59$ \\
\hline $\begin{array}{c}\text { Glomus hoi and } \\
\text { Acaulospora } \\
\text { kentinensis }\end{array}$ & $0.26 \pm 0.23$ & $2.91 \pm 0.04$ & $3.17 \pm 0.14$ & $0.092 \pm 0.03$ & $0.651 \pm 0.12$ & $0.743 \pm 0.58$ \\
\hline control & $0.13 \pm 0.20$ & $1.20 \pm 0.01$ & $1.33 \pm 0.12$ & $0.086 \pm 0.02$ & $0.338 \pm 0.03$ & $0.424 \pm 0.53$ \\
\hline
\end{tabular}


Table 6. Biochemical parameters ( $\mathrm{mg} /$ gram fresh weight)

\begin{tabular}{|c|c|c|c|c|c|}
\hline Species & $\begin{array}{c}\text { Reducing sugar } \\
\text { (Average } \pm \\
\text { Standard error) }\end{array}$ & $\begin{array}{c}\text { Non Reducing Sugar } \\
\text { (Average } \pm \\
\text { Standard error) }\end{array}$ & $\begin{array}{c}\text { Total Carbohydrate } \\
\text { (Average } \pm \\
\text { Standard error) }\end{array}$ & $\begin{array}{c}\text { Total Protein } \\
\text { (Average } \pm \text { Standard } \\
\text { error) }\end{array}$ & $\begin{array}{c}\text { Total Phenol } \\
\text { (Average } \pm \text { Standard } \\
\text { error) }\end{array}$ \\
\hline Glomus hoi & $4.69 \pm 0.24$ & $174.29 \pm 5.24$ & $178.96 \pm 7.68$ & $4.23 \pm 0.32$ & $0.070 \pm 0.03$ \\
\hline $\begin{array}{c}\text { Acaulospora } \\
\text { kentinensis }\end{array}$ & $5.19 \pm 0.14$ & $183.29 \pm 4.31$ & $198.96 \pm 6.58$ & $5.33 \pm 0.23$ & $0.083 \pm 0.02$ \\
\hline $\begin{array}{c}\text { Glomus hoi } \text { and } \\
\text { Acaulospora } \\
\text { kentinensis }\end{array}$ & $5.13 \pm 0.14$ & $184.29 \pm 4.21$ & $199.96 \pm 6.48$ & $5.43 \pm 0.33$ & $0.093 \pm 0.03$ \\
\hline control & $10.19 \pm 0.32$ & $109.60 \pm 4.62$ & $119.79 \pm 5.14$ & $3.39 \pm 0.12$ & $0.630 \pm 0.03$ \\
\hline
\end{tabular}

\section{Biochemical parameters}

Inoculation of AMF spores increases the biochemical parameters of cow pea plant. Non reducing sugars, total sugars, total protein and total phenol were high in plants inoculated with the combinations of species Glomus hoi and Acaulospora kentinensis. While reducing sugars was high in the plants inoculated with Acaulospora kentinensis plants without the inoculation of AMF species shows minimum concentration of reducing sugars, non reducing sugars, total sugars, total protein and total phenol (Table 6)

\section{Discussion}

Modern cowpea cultivars are still responsive to mycorrhizal inoculation suggesting that modern breeding programs are not deleterious AMF symbiosis (Oruru et al., 2018). AMF are beneficial soil symbionts which establish mutualistic association with the roots of $80 \%$ of Plant species and the large majority of food crops including cereals, Legumes vegetables and fruits (Pepeet al., 2018). Arbuscular mycorrhizal fungi increase the growth of some plants like Spilanthes calva, Withania somnifera, Cartanospermum austral, Cymbopogon martini, Phyllanthus amarus, Gloriosa superba and Pueraria tuberose (Shenbagam, 2008). Arbuscular mycorrhizal fungi contribute to the primary and secondary metabolism of plants and increases active ingredients of medicinal and aromatic plants (Tarraf et al., 2017). Arbuscular mycorrhizal fungi contribute to the primary and secondary metabolism of plants and increases active ingredients of medicinal and aromatic plants (Tarraf et al., 2017). Arbuscular mycorrhizal fungi enhance the production of secondary metabolites in plants like alkaloids, terpenoids and phenolics, which are very much useful to humans. The role of Arbuscular mycorrhizal fungi in the amplification of secondary metabolite content has attained enormous recognition for sustainable cultivation of medicinally important plants. Therefore, AMF plays a vital role in the better accumulation of bioactive compounds in host plants (Pandey et al., 2018). Inoculation of AMF optimizes the production of bioactive compounds in the plants which in turn increases the production of secondary metabolites. In those plants which show AMF association the flavonoid concentration increases as reported in Libidubia ferrea in the field conditions (Santos et al., 2017). Arbuscular mycorrhiza fungi (AMF) colonize roots of host plants and promote plant growth due to improved uptake of nutrients like $\mathrm{P}$, $\mathrm{Mn}, \mathrm{K}, \mathrm{Cu}$, and Fe in Chickpea (Farzaneh et al., 2011). Arbuscular mycorrhizal fungi are a good candidate for promoting plant growth and essential oil composition and improving Phosphorous uptake in low fertility soils (Tarraf et al., 2017).

\section{Conclusions}

Cowpea is an important legume grown primarily in semi-arid area. Its production is generally inhibited by various abiotic and biotic stresses. The use of beneficial microorganisms (e.g., plant growth promoting bacteria (PGPB) and arbuscular mycorrhizal fungi (AMF)) can enhance agricultural production, as these microorganisms can improve soil fertility and plant tolerance to environmental stresses, thus enhancing crop yield in an eco-friendly manner. The application of beneficial soil microorganisms can be a viable approach for sustainable cowpea production in precision agriculture scenarios (Ma et al., 2019) Cow pea has a good mycotropic status and it has arbuscules and vesicles are found in its roots. It shows the symbiotic association with Glomus hoi and Acaulospora kentinensis. The partners in this association are members of fungi (Basidiomycetes, Ascomycetes, and Zygomycetes) and most of the vascular plants. Fitter and Moyersoen (1996) provided a succinct definition -"a sustainable nonpathogenic biotropic interaction between a fungus and root". In the mycorrhizal literature, the term symbiosis is used to describe a highly interdependent mutualistic relationship where the host plant receives mineral nutrients while the fungus obtains photosynthetically derived carbon atoms. The present study pertains that AMF colonization improved positively the overall growth and development of cow Pea plant. Chlorophyll, Reducing sugars, Non Reducing sugars, Total sugars, Total protein and Total phenol content too was found higher in AMF inoculated than control. 


\section{Acknowledgement}

Authors are thankful to Head School of studies in Botany, Jiwaji University Gwalior for all possible help. Authors are also helpful to Dr. Reena Singh TERI New Delhi for providing Mycorrhizal spores

\section{Author Contribution}

SAT and SP designed the study. SAT performed the practical work, analyzed the data and wrote the manuscript. SP supervised the study.

\section{Funding}

No funding was given by any agency for this study.

\section{Compliance with Ethical Standards Conflict of Interest}

The authors declare that they have no conflict of interest

\section{Ethical Approval}

The study does not involve any research on Humans or Animals.

\section{Informed Consent}

Informed consent was obtained from all individual participants included in the study

\section{REFERENCES}

[1] Arnon, D. I. (1949). Copper enzymes in isolated chloroplasts. Polyphenoloxidase in Beta vulgaris. Plant physiology, 24(1), 1.

[2] Biermann, B., \& Linderman, R. G. (1981). Quantifying vesicular towards standardization. New Phytologist, 87(1), 63-67.

[3] Fitter, A. H. and Moyersoen, B. 1996. Evolutionary trends in root microbes symbioses. Phil. Trans. R. Soc. Lond. B 351, $1367-1375$.

[4] Gianinazzi, S., Gollotte, A., Binet, M. N., van Tuinen, D., Redecker, D., \& Wipf, D. (2010). Agroecology: the key role of arbuscular mycorrhizas in ecosystem services.
Mycorrhiza, 20(8), 519-530.

[5] Gondwe, T. M., Alamu, E. O., Mdziniso, P., \& Maziya-Dixon, B. (2019). cowpea (Vigna unguiculata (L.) Walp) for food security: an evaluation of end-user traits of improved varieties in Swaziland. Scientific reports, 9(1), 16.

[6] Hedge, J. E \& Hofreiter, B. T. (1962). Estimation of carbohydrate. Methods in carbohydrate chemistry. Academic Press, New York, 17-22.

[7] Johnson, N. C., Wilson, G. W., Wilson, J. A., Miller, R. M., \& Bowker, M. A. (2015). Mycorrhizal phenotypes and the Law of the Minimum. New Phytologist, 205(4), 1473-1484.

[8] Kobae, Y., Kawachi, M., Saito, K., Kikuchi, Y., Ezawa, T., Maeshima, M., \& Fujiwara, T. (2015). Up-regulation of genes involved in $\mathrm{N}$-acetylglucosamine uptake and metabolism suggests a recycling mode of chitin in intraradical mycelium of arbuscular mycorrhizal fungi. Mycorrhiza, 25(5), 411-417.

[9] Kyei-Boahen, S., Savala, C. E., Chikoye, D \& Abaidoo, R. (2017). Growth and yield responses of cowpea to inoculation and phosphorus fertilization in different environments. Frontiers in plant science, 8, 646.

[10] Lone, R., Shuab, R., Sharma, V., Kumar, V., Mir, R., \& Koul, K. K. (2015). Effect of arbuscular mycorrhizal fungi on growth and development of potato (Solanum tuberosum) plant. Asian Journal of Crop Science, 7(3), 233- 243.

[11] Lowry, O. H., Rosebrough, N. J., Farr, A. L., \& \& Randall, R. J. (1951). Protein measurement with the Folin phenol reagent. Journal of biological chemistry, 193, 265-275.

[12] Pepe, A., Giovannetti, M., \& Sbrana, C. (2018). Lifespan and functionality of mycorrhizal fungal mycelium are uncoupled from host plant lifespan. Scientific reports, 8(1), 10235 .

[13] Santos, E. L. D., Alves da Silva, F., \& Barbosa da Silva, F. S. (2017). Arbuscular Mycorrhizal Fungi Increase the Phenolic Compounds Concentration in the Bark of the Stem of Libidibia Ferrea in Field Conditions. The Open Microbiology Journal, 11(1).

[14] Shuab, R., Malla, N. A., Ahmad, J., Lone, R., \& Koul, K. K. (2016). Arbuscular mycorrhizal fungal symbiosis with saffron (Crocus sativus L.) Plant. J. New Biol. Rep, 5(8).

[15] Smith, F. A., \& Smith, S. E. (2013). How useful is the mutualism-parasitism continuum of arbuscular mycorrhizal functioning? Plant and Soil, 363(1-2), 7-18.

[16] Somogyi, M. (1952). Determination of reducing sugars by Nelson-Somogyi method. J. Biol. Chem, 200, 245. -arbuscular mycorrhizae: a proposed method

[17] Urcelay, C., Longo, S., Geml, J., \& Tecco, P. A. (2019). Can arbuscular mycorrhizal fungi from non-invaded montane ecosystems facilitate the growth of alien trees?. Mycorrhiza, 29(1), 39-49.

[18] Van Der Heijden, M. G., Martin, F. M., Selosse, M. A., \& Sanders, I. R. (2015). Mycorrhizal ecology and evolution: the past, the present, and the future. New Phytologist, 205(4), 1406-1423. 